\title{
REAL ESTATE BROKERS AND THE COURTS
}

\author{
HarRy WgLLeR HILL*
}

The services of real estate brokers have come to include the drawing of contracts, conveyances and other instruments essential to the closing of the transactions which they have negotiated. Exception to the performance of this service by persons not authorized to practice law has been taken by the legal profession in a series of cases, most of which are of recent date.

In defense of their practice, the real estate brokers have relied on the following contentions: ( $\mathrm{I}$ ) the drawing of legal instruments does not constitute the practice of law. (2) Even if the drawing of "complex instruments" may be the practice of law, this is not true of the drawing of "simple instruments." (3) Although the drawing of instruments solely for others may constitute the practice of law, the broker is entitled to draw instruments incidental to his business, or (4) for which he receives no compensation. (5) Where the broker is licensed by the state and his license is conditioned on a showing of knowledge of the principles of conveyancing law, he is entitled to draw real estate instruments. All these propositions, of course, do not appear in any single case, although two or more have been advanced in some cases. However, for the purpose of this note, the treatment accorded by the courts to each of these contentions will be considered separately.

(I) The first contention, that the drawing of legal instruments does not constitute the practice of law, finds little support in the cases. Although one case has held that the preparing and drawing of conveyances for others is not the practice of law ${ }^{1}$ (which has since been overruled) ${ }^{2}$ and one court has intimated that if legal advice were not given with the drawing of the instrument it might not be the practice of law, ${ }^{3}$ the decisions overwhelmingly have held that the practice of law includes the preparation and drawing of legal instruments, such as warranty deeds, quitclaim deeds, mortgages, leases, building contracts, etc. ${ }^{4}$ Some statutes which attempt to

* University of Alabama, I932-33, Marshall College, 1933-1935. Now a member of the third year class, Duke University School of Law. Member of the Editorial Board of the Duke Bar Association lournal.

${ }^{2}$ Atlanta Title \& Trust Co. v. Boykin, 172 Ga. 437, 157 S. E. 455 (193x); sec dissent of Putnam, J., in People v. Title Guarantee \& Trust Co., 180 App. Div. 648, 655, 168 N. Y. Supp. 278, 284, 285 (19:7); dissent of McLaughlin, J., in People v. Alfani, 227 N. Y. 334, 343, 344, 125 N. E. 671, 674, 675 (1919).

Boykin v. Hopkins, I74 Ga. 5 rx, I62 S. E. 796 (1932).

${ }^{3}$ In re McCallum, 186 Wash. 312, 314, 57 P. (2d) 1259, r260 (1936). However, the same court seems to assume that the drawing of instruments is the practice of law in ln re Estes, 186 Wash. 690, 57 P. (2d) 1262 (1936).

"People ex rel. Los Angeles Bar Ass'n v. California Protective Corp., 76 Cal. App. 354, 244 Pac. 1089 (1926); Yeats v. Cunningham (Circ. Ct., Fla. 1936), Brand, Unauthorized Practice Decisions (1937) 
define the practice of law specifically include the drawing of any paper relating to secular rights." In Opinion of the Justices, the Massachusetts court said, "Practice of law under modern conditions consists in no small part of work performed outside of any court and having no immediate relation to proceedings in court. It embraces conveyancing, the giving of legal advice on a large variety of subjects, and the preparation and execution of legal instruments covering an extensive field of business and trust relations and other affairs." 6

Since conveyances and like instruments are in their very nature designed to transfer or at least affect certain rights and powers of individuals, then it is said that it is as important in the public interest that the drawing of such papers be done only by trained, licensed attorneys as that court work be handled only by them. ${ }^{7}$ In the New York case of People v. Alfani, Crane, J., writing the opinion of the court, said, "Any judge of much active work on the bench has had frequent occasion to guide the young practitioner, or protect the client from the haste or folly of an older one. Not so in the office. Here the client is with his attorney alone, without the impartial supervision of a judge. Ignorance and stupidity may here create damage which the courts of the land cannot thereafter undo. Did the legislature mean to leave this field to any person out of which to make a living? Reason says no."8

(2) The contention which would except "simple instruments" from the operation of the rules established by the preceding cases has more judicial support. Some courts have made a distinction between the drawing of skeleton blank or stereotyped forms, such as a simple deed or mortgage not involving "special facts or conditions," and an instrument which must be shaped from a large number of facts, by holding that a layman may draw simple instruments for others without being engaged in the practice of law. ${ }^{9}$ The most quoted statement for this position is in In re Eastern Idaho Loan \& Trust Co. where the Idaho court said, "Defendants contend that their specially advertized activities do and did not constitute practicing law; that they but do and did what hordes of reputable insurance men, realtors, and bankers have been doing for years, and what chapter 192, sec. 2 of the Session Laws of 1929 authorized

585; In re Matthews, 62 P. (2d) 578 (Idaho 1936 ); People ex rel. Ill. State Bar Ass'n v. People's Stock Yards State Bank, 344 Ill. 462, I76 N. E. 901 (r93I); State ex rel. Wright v. Barlow, I3I Neb. 294, 268 N. W. 95 (1936); People v. Alfani, supra note I; Cain v. Underwood (Dist. Ct., N. D. r935), Brand, op. cit. supra at 416; Land Title Abstract \& Trust Co. v. Dworken, 129 Ohio St. 23, 193 N. E. 650 (1934); State Bar v. Farmers and Merchants Bank (Dist. Ct., Okla. I936), Brand, op. cit. supra at 545; Johnson v. Litster (Dist. Ct., Utah 1936), id. at 575; Paul v. Stanley, I68 Wash. 37I, I2 P. (2d) 40I (1932); 22 Op. ATT. GeN. WIs. (1933) 827.

¿See, e. g., Ala. Code (I928) \$6248; I LA. Gen. Stat. (Dart, I932) \$443; 2 Mrss. Code (I930) \$3710; 2 Mo. Rev. STAt. (xg29) \$II692; TEx. STAT. (2d Supp. I934) art. 430a, \$2.

${ }_{289}$ Mass. 607, 613, 194 N. E. 313, 317 (1935).

${ }^{7} I d$, at $6 \mathrm{r}_{4}, \mathrm{I} 94 \mathrm{~N}$. E. at $3 \mathrm{I7}$.

${ }^{8}$ Supra note I at 339,340 , I25 N. E. at 673 .

- People v. Title Guarantee \& Trust Co., 227 N. Y. 366 , 125 N. E. 666 (I9r9), discussed in the text, infra, p. 74; see Harman v. Berry, 2 Sup. Ct., D. C. (N. S.) 5 (1935); In re Eastern Idaho Loan \& Trust Co., 49 Idaho 280, 285, 286, 288 Pac. I57, 159 (1930); People ex rel. Ill. State Bar Ass'n v. People's Stock Yards State Bank, stipra note 4 at 477,478 , x76 N. E. at 908; Crawford v. McConnell, r73 Okla. 520, 523, 49 P. (2d) 551, 555, 556 (1935); cf. Cain v. Merchants Nat. Bank \& Trust Co., 66 N. D. 746, 754, 268 N. W. $719,723(1936)$. 
them to do. Such work as the mere clerical filling out of skeleton blanks or drawing instruments of generally recognized and stereotyped form effectuating the conveyance or incumbrance of property, such as a simple deed or mortgage not involving the determination of the legal effect of special facts and conditions, is generally regarded as the legitimate right of any layman." 10 In referring to this statement, the same court in In re Matthews, a decision holding that the drawing of simple deeds and real estate mortgages was the practice of law, said, to distinguish the two cases, "As a matter of fact, a careful reading of the said matter which immediately precedes the quotation relied upon by defendant Matthews at once discloses a mere mistake in punctuation, in this, that a period was used instead of a comma" between the two sentences quoted above. ${ }^{11}$ It is submitted that this repunctuation of the earlier case does not change in the least the substance of its meaning, and hence the later decision in effect has overruled the earlier.

Other courts hold no distinction can be made-that the filling in of blank forms or the drawing of simple instruments is just as much the practice of law as the drawing of a very complex document. ${ }^{12}$ Although in People $v$. Title Guarantee \& Trust Co., ${ }^{13}$ the opinion of the court, prepared by Hiscock, C. J., rested the reversal of a conviction for the unlawful practice of law on the basis of this distinction, the distinction was repudiated by four of the seven judges and not relied upon by a fifth. In concurring in the result on other grounds, Pound, J., said, "I am unable to rest any satisfactory test on the distinction between simple and complex instruments. The most complex are simple to the skilled, and the simplest often trouble the inexperienced."14 In a dissenting memorandum prepared by Cardozo, J., for himself and two other judges, Judge Pound's view was expressly adopted.

Even in the preparation of a simple instrument of blank form, some courts feel a layman does not know definitely that such an instrument is suited to the particular circumstances, for he does not know ordinarily the exact legal effect of the stereotyped words and clauses in the instrument. Therefore the filling in of a printed form has been held to constitute a determination of the legal effect of special facts and conditions. ${ }^{15}$ In In re Gore, an Ohio Common Pleas court made this statement: "While some confusion seemingly has arisen with reference to the mere 'filling in of blanks' as it is expressed, there can be no doubt that the selection of the form to be used and that the determination by the broker of the suitability and adaptability of the form to the circumstances of the transaction involves the exercise of legal skill and learning."16

The American Bar Association Committee on Unauthorized Practice has said that

${ }^{20}$ Supra note 9 at 285, 286, 288 Pac. at 159 . In In re Matthews, supra note 4 at 581 .

${ }^{12}$ Clark v. Reardon, 104 S. W. (2d) 407 (Mo. App. 1937); Cain v. Underwood, stupraz note 4 ; In re Gore (Common Pleas Ct., Ohio 1936), Brand, op. cit. supra note 4 at 472, afjd, Ohio Ct. of App. $2 \mathrm{~d}$. dist., Dec. 30, 1937 (1938) то OHо BAR 5II; State Bar v. Farmers and Merchants Bank, stipra note 4; Paul v. Stanley, stipra note 4 .

${ }^{73}$ Supra note 9. $\quad$ "Stupra note 9 at 379, 125 N. E. at 670.

${ }^{15}$ In re Rathke (Circ. Ct, Mich. 1936), BRAND, op. cit. supra note 4 at 614 , In re Gore, supra note 12.

${ }^{30}$ In re Gore, supra note 12. 
it is not against public interest for one not licensed to fill in the blanks of legal instruments appropriately, if they have been selected by one licensed to practice law, and are used for the particular purpose only within a reasonable time after such advice and selection. ${ }^{17}$

(3) The real estate brokers' contention that they may draft instruments for the parties to transactions which they have negotiated rests on the principle that anyone who is a party or principal in a transaction may draw the instruments or do any other 'legal work in relation thereto. ${ }^{18}$ As stated in Judd v. The City Trust \& Savings Bank, "Since practicing law involves the performance of services for others, any individual is accorded the right to do his own legal work either in court or out."19 The courts are divided whether this principle may be extended to protect the broker who, though neither party nor principal, yet has a substantial interest in the transaction.

In the Pennsylvania case of Childs v. Smeltzer, it was said that if the drawing of an instrument, such as a deed or lease, is a concomitant of an unlicensed person's business, or grows out of a business transaction in which he is interested, he may prepare such a paper for the parties. ${ }^{20}$ The court in this case said, "A real estate broker is not prohibited from drawing a deed or conveyance or other appropriate instrument relating to property of which he or his associates have negotiated a sale or lease." ${ }^{21}$ Under this view it seems immaterial whether the instrument is a blank form, simple, or complex, although one case stated that an unlicensed person may draw simple deeds and mortgages if they are incidental to transactions in which he is interested, provided no charge is made. ${ }^{22}$ The Childs case is in conflict with the decisions of three courts, ${ }^{23}$ two of which state that it is not sound to allow a real estate broker to draw such instruments because he has a conflicting interest arising from the fact that his compensation depends upon the successful closing of the transaction. $^{24}$ No court seems to have adverted to a further reason advanced by the American Bar Association Committee on Unauthorized Practice, which said, "Almost every phase of the law would be deemed to be, by the various trades, pro-

${ }^{27} 6$ I AM. BAR Ass'N ReP. (1936) 7 II.

${ }^{28}$ Copeland v. Dabbs, 221 Ala. 489 , I29 So. 88 (1930); State Bar v. Farmers and Merchants Bank, supra note 4 .

${ }^{20} 133$ Obio St. 81, 91 (1937). If an unlicensed person acts as an amanuensis in drawing an instrument as dictated to him by a principal to the transaction, such as a vendor or purchaser, he is held not to be practicing law. State ex rel. Wright v. Barlow, supra note 4; Land Title Abstract \& Trust Co. v. Dworken, supra note 4. For example, if an unlicensed person were to draw an instrument for himself by dictating it to a stenographer, or were to tell the stenographer to obtain a certain blank form and insert data therein which he has given her, the stenographer would; not be engaged in the practice of law, for the selection of the instrument and the determination of the material to be put in is the act of the employing party, the stenographer merely performing the mechanical act of recording.

${ }^{515}$ Pa. 9, I7I Atl. 883 (I934); see also Pound, J., in People v. Title Guarantec \& Trust Co., supra note 9 at $380,125 \mathrm{~N}$. E. at 670 .

7 Childs v. Smeltzer, supra note 20 at 14, 15, I71 Atl. at 886.

$\approx$ Cain v. Merchants Nat. Bank \& Trust Co., supra note 9 at 754,268 N. W. at 723.

${ }^{3}$ In re Brainard, 55 Idaho 153, 39 P. (2d) 769 (1934); In re Abbey (Circ. Ct., Mich. I934), Brand, op. cit. supra note 4 at 244; In re Gore, supra note 12 .

"In re Abbey, supra note 23; In re Gore, supra note 12. 
fessions, businesses, and 'services,' purely ancillary and incidental to some one or more of them."25

(4) The importance of the fourth contention, relating to the presence or absence of compensation, rests on the fact that real estate brokers who draw papers for their clients generally make no charge therefor where they are effectuating a deal for the parties. Some statutes which attempt a definition of the practice of law state that the drawing of instruments is the practice of law where done for a consideration, ${ }^{26}$ reward, ${ }^{27}$ or pecuniary benefit, present or anticipated.8 In England, a layman was not fined for transacting business pertaining to the office of a public notary unless he did so for or in expectation of any gain, fee, or reward.29 Most courts have taken the view that a consideration or compensation is needed before the preparing of legal papers can be said to be the practice of law. ${ }^{30}$ If there is compensation in money, the drawing of instruments is yet the practice of law even though the compensation may not be paid by the client. ${ }^{31}$ The amount of the consideration is also immaterial. ${ }^{32}$

Since, even where the preparation is done without a charge, the parties to a transaction are, of course, still liable to be injured if the layman preparing the papers is ignorant or inexperienced, the American Bar Association Committee on Unauthorized Practice has argued that "the presence, or absence, of consideration is not a proper distinguishing element by which to determine the existence of unlawful practice. Whether or not it is present in no way limits the injury to the profession, or, what is more important, to the public."33 Two cases substantiate this position by holding that even without compensation the drawing of deeds, mortgages and similar instruments for others by a layman constitutes the unlawful practice of law..$^{34}$ In State ex rel. Wright v. Barlow, the court said, "Defendant insists that to constitute the practice of law one must hold himself out as a licensed attorney and receive a fee for his service. We think that this claim is not well founded. . . It might as well be said that a surgeon who performs, without fee or reward, a tonsillectomy or appendectomy is not practicing surgery." 35

The defense that no compensation is received for drafting papers must be interpreted to mean that no payment is received specifically for this service. The drawing of instruments is one among several services which a real estate broker performs, and for which he is compensated in a lump sum in the form of his commission. Thus,

$\approx$ 60 AM. BAR Ass'N REP. (1935) 534 .

${ }^{3}$ Mo. Rev. Stat., supra note 5; see State ex inf. Miller v. St. Louis Union Trust Co., 335 Mo. 845, 74 S. W. (2d) 348 (r934) holding that the nomination of a trust company as executor or trustee was a "valuable consideration" for the drafting of wills and trust agreements.

${ }^{27}$ Miss. CODE, supra note 5.

${ }_{23}^{3}$ Ala. Code, supra note 5; La. Gen. Stat., stspra note 5; Tex. Stat., stipra note 5.

20 \& 7 Vicr., c. 90 ( 1843 ).

${ }^{\infty}$ Yeats v. Cunningham, supra note 4; Childs v. Smeltzer, supra note 20; Paul v. Stanley, supra note 4; see Clark v. Reardon, supra note 12 at 409.

${ }^{31}$ Ferris v. Snively, I72 Wash. 167, I9 P. (2d) 942 (1933).

see In re Matthews, supra note 4 at 580. $\quad \approx 60$ AM. BAR Ass'N REP. (I935) 533.

${ }^{3}$ State ex rel. Wright v. Barlow, supra note 4; State Bar v. Farmers and Merchants Bank, supra note 4 .

${ }^{2}$ Supra note 4 at $296,297,268$ N. W. at 96 . 
there is a consideration or compensation for this service in a broad sense. Of course, his commission is not paid solely for his having drafted the instruments to the transaction for the parties, but it is also assertable that neither is his bringing together of the vendor and purchaser or lessor and lessee the entire object for which his commission is paid. Whether or not a real estate broker draws papers for a direct charge, his purpose is to bring the transaction to a close and thereby make a profit in the form of a commission. Hence it would be difficult to find an instance where no compensation existed. ${ }^{36}$

(5) That the drafting of legal instruments for others has not always been the exclusive province of the lawyer is shown by the fact that public notaries in England have had the privilege of writing conveyances of realty and of drawing legal instruments for others. ${ }^{37}$ Still, this privilege could not be engaged in by the ordinary layman, but was limited to these notaries in order to protect the public against inexperienced persons. ${ }^{38}$ In order to ensure trained persons for this work, no one could be admitted as a public notary in England until he had actually served seven years as an apprentice, ${ }^{30}$ and an applicant was subject to be required to show character qualifications. ${ }^{40}$ Any person doing anything for gain pertaining to the office of a public notary was subject to a fine of $£ 5^{0,4 I}$ and if a public notary allowed his name to be used for the profit of another person not entitled to act as a public notary, he should be forever disabled from practicing as a public notary. ${ }^{42}$

Against the contention that, since the judiciary has the inherent power to define and regulate the practice of law, any legislative enactment which stultifies this power is unconstitutional, ${ }^{43}$ the existence of this privilege on the part of notaries in England might afford a basis for sustaining a statute according like powers to notaries (and even real estate brokers) in this country, at least if they were required to meet comparable standards. However, it is scarcely precedent for an extension of the privilege to persons not specially authorized to perform such acts. Two statutes do

${ }^{20}$ In a copyright infringement action wherein a restaurant orchestra had performed a copyrighted musical composition without charge for admission, it was held to have performed the work publicly "for profit." In speaking for the court Mir. Justice Holmes said, "The defendants' performances are not cleemosynary. They are part of a total for which the public pays, and the fact that the price of the whole is attributed to a particular item [food] which those present are expected to order, is not important. It is true that the music is not the sole object, but neither is the food, which probably could be got cheaper elsewhere. . . . If music did not pay, it would be given up. If it pays it pays out of the public's pocket. Whether it pays or not the purpose of employing it is profit and that is enough." Herbert v. The Shanley Co., 242 U. S. 591, 594, 595 (I917).

${ }^{5} 24$ Halsbury's Laws of ENG. (2d ed. I937) §I; Hutcheon v. Mannington, 6 Ves. 823, 824 (Ch. 1802). Notaires in France are also allowed to draft instruments. FreNCH CrviL Code (Wright's trans. 1908) arts. 971, 972, 1317, and 2127. Notaries in this country are unlike the continental notaries. As said by Crane, J., "Only in the name is there a correspondence to the continental official." People v. Alfani, supra note $\mathrm{I}$ at $340,34 \mathrm{I}$, I25 N. E. at 674 .

${ }_{28}$ Halsbury's Laws of ENG. (2d ed. I93I) \$682; Taylor v. The Crowland Gas \& Coke Co., Io Exch. 293 (Ex. 1854 ).

${ }_{41}$ Geo. III, c. 79 (I80I). The King v. Scriveners' Co., Io B. \& C. 5 II (K. B. I830).

${ }^{\infty} 6$ \& 7 VicT., c. 90 (I843).

4I Ibid.

${ }_{4}^{4}$ I GEO. III, c. 79 (180I).

${ }^{4}$ Muenier v. Bernich, I70 So. 567 (La. App. 1936); Opinion of the Justices, supra note 6. 
allow a real estate broker to draft instruments for the parties to a transaction he has negotiated, ${ }^{44}$ and a statute of Delaware allows any person on payment of a license fee to draw conveyances and any other papers, no qualifications apparently being required. ${ }^{45}$

In a number of states, real estate brokers are required to be licensed, although the statutes are silent as to whether the privilege to draft instruments is conferred by the license. As a prerequisite to obtaining a license, in a few of these states, the statute requires the applicant to pass an examination, showing among other things that he has a fair knowledge of the principles of real estate conveyancing pertaining to deeds, mortgages, land contracts, leases, etc. A New York statute is as follows: "In determining the competency, the department shall require proof that the applicant for a broker's license has a fair knowledge of the English language, a fair understanding of the general purposes and general legal effect of deeds, mortgages, land contracts of sale, and leases, a general and fair understanding of the obligations between principal and agent, as well as of the provisions of this act, and that he has been engaged in the real estate brokerage business for a period of not less than one year immediately preceding the date of filing his application for a license under this article."40 A Michigan statute, after providing for an examination of the applicant's character, adds the provision: "The Commission shall also require each applicant for broker's license to pass an examination establishing, in a manner satisfactory to the commission, that the applicant has . . . a fair understanding of the laws and principles of real estate conveyancing, deeds, mortgages, land contracts, leases, the obligations of a broker to the public and his principal, . ."47 Since licensed real estate brokers in these states have some training and experience, they cannot be said to fall precisely in the category of an untrained layman. ${ }^{48}$

In the only case to interpret a licensing statute of this character, Detroit Bar Association v. Ward, a Michigan circuit court was apparently of the opinion that a "fair understanding" of conveyancing was insufficient to qualify a real estate broker to draw leases, contracts, and deeds for others. In that case the court said, "We all realize that in the writing of examinations on certain subjects that a certain general knowledge of many subjects is required but I do not feel in this instance it would go so far as to admit of a real estate broker being entitled to give out information with regard to law and the drafting of legal instruments because the rules of the Securities Commission pertaining to the examination of real estate brokers demanded certain questions with respect to law and legal papers be included in the examination." ${ }^{40}$

Although there have been a few statements and intimations that an isolated act or a single transaction, such as the drawing of one instrument for another without

\footnotetext{
4 r MD. Ans. Code (Bagby, I924) art. 10, §I (as to several counties); R. I. Acts \& Resolves, Sp. Sess., 1935, c. 2190, $\$ 46$, cl. B, par. 7 .

${ }^{48}$ N. Y. Consol. Laws (Cahill, 1930) c. 51, \$44I. $\quad{ }^{47} 2$ Mrch. Comp. Laws (1930) \$9813.

49 There is some similarity between the qualifications required in the above and similar statutes concerning the English notary.

19 (Circ. Ct., Mich. I934), Brand, op. cit. stspra note 4 at 249, 252, 253.
} 
making a practice of doing such, will not constitute the practice of law, ${ }^{50}$ and two New York cases have so held, ${ }^{51}$ two other courts have held that such isolated acts are nevertheless the practice of law. ${ }^{52}$ But if the acts of unlawful practice are infrequent and few, no injunction will be granted against the future occurrence of similar acts where they are unlikely to happen. ${ }^{53}$ The American Bar Association Committee on Unauthorized Practice has said that "there seems to be no good reason why the acts of one who has no right to do what he is attempting to do should be altogether free from challenge until and unless his conduct has the continuity of, or has reached such volume that it is a 'practice,' 'business,' or a 'profession'."54 However, the Committee also added that "it has no slightest desire that steps to eliminate unlicensed acts be based on technicalities, or on occasional sporadic, isolated, acts." 55

Real estate problems have given rise to a number of points of controversy between the bar and lay agencies other than those relating to the drafting of legal documents. For example, the handling and prosecuting of eviction proceedings $\mathrm{s}^{\mathbf{5} 6}$ and foreclosure proceedings $^{57}$ by an unlicensed person or a corporation for its landlord clients is considered to be the unlawful practice of law. The activities of abstract and title companies have been especially prolific of litigation in this field, but these cases lie outside the scope of this note. 58

${ }^{\infty}$ Crane, J., in People v. Title Guarantee \& Trust Co., stepra note 9 at 615 , 125 N. E. at 67I; Childs v. Smeltzer, stupra note 20 at 14, I7I Adl. at 885; 22 Op. ATr. GEN. Wis. (1933) 828. In Opinion of the Justices, supra note 6 at 615,194 N. E. at 317 , the court said, "The oceasional drafting of simple deeds, and other legal instruments when not conducted as an occupation or yielding substantial income may fall outside the practice of the law."

${ }^{a}$ People v. Goldsmith, 249 N. Y. 586, I64 N. E. 593 (I928), reversing 224 App. Div. 707, 229 N. Y. S. 896 (1928); People v. Weil, 237 App. Div. 118, 260 N. Y. Supp. 658 (1932).

as Wayne v. Murphey-Favre \& Co., 56 Idaho 788, 59 P. (2d) 721 (1936); In re Rathke, stupra note 15.

${ }^{6}$ Cain v. Merchants Nat. Bank \& Trust Co., supra note 9.

460 Ars. Bar Ass'n Rep. (1935) 535 . $1 d$. at 536.

${ }^{5}$ Heiskell v. Mozie, 65 App. D. C. 255, 82 F. (2d) 861 (I936); Harman v. Berry, stupra note 9; Yeats v. Law (Circ. Ct. Fla. Y934), Brand, op. cit. supra note 4 at 324; Chicago Bar Ass'n v. Nat. Landlords Ass'n (Super. Ct., Ill. 1936), id. at 583; Unger v. Landlords' Management Corp., Ir4 N. J. Eq. 68, I68 Atl. 229 (1933); Bennett v. Tenants Research Bureau (Sup. Ct., N. Y. I936), BRANd, op. cit. supra at 562 (consent decree); Dworken v. Department [Apartment] House Owner's Ass'n, 28 Ohio N. P. Rep. II5 (1930). A contrary decision is Sharp-Boylston Co. v. Haldane, $x 82$ Ga. 833, 187 S. E. 68 (1936), but this decision has been nullified by a later statute in Georgia which provides that no party shall prepare or file affidavits based upon dispossessory warrants, distress warrants, or attachments, or prosecute the proceedings through any agent or employee who is not a duly licensed attorney-at-law. Ga. Laws 1937, p. 753.

"T In re Otterness, 18I Minn. 254, 232 N. W. 318 (r930).

${ }^{63}$ The cases are collected in Brand, op. cit. supra note 4 at 764 . 